\title{
PEMANFAATAN ABU SEKAM PADI MENJADI KATALIS HETEROGEN DALAM PEMBUATAN BIODIESEL DARI MINYAK SAWIT
}

\author{
Kusyanto \& Purwa Aditya Hasmara \\ Jurusan Teknik Kimia, Politeknik Negeri Samarinda \\ Kampus Gn. Lipan, Jl. Cipromangunkusumo, Samarinda 75131 \\ Email: yanto_koes@yahoo.com
}

\begin{abstract}
ABSTRAK
Berdasarkan data BPS Kaltim (2014) jumlah produksi padi mencapai 432.612 ton/tahun. Produksi padi tersebut menghasilkan sekam padi rata-rata sebesar 20\%. Sekam padi masih kurang dimanfaatkan dengan baik sehingga hanya menjadi tumpukan limbah pertanian. Abu sekam padi mengandung senyawa yang dapat digunakan sebagai support katalis yaitu diantaranya $\mathrm{SiO}_{2}$. Penelitian ini bertujuan untuk mengetahui pengaruh penambahan abu sekam padi yang telah dikalsinasi dengan impregnasi $\mathrm{KOH}$ sebagai katalis pembuatan biodiesel dari minyak sawit secara konvensional. Sekam padi dikalsinasi pada suhu $500^{\circ} \mathrm{C}$ selama 3 jam lalu diimpregnasi dengan $\mathrm{KOH}$ 1,9 $\mathrm{N}$. Kemudian dibilas dengan aquadest dan dioven hingga beratnya konstan. Transesterifikasi dilakukan pada minyak sawit dengan perbandingan massa terhadap volume minyak $(10 \%, 15 \%, 20 \%, 25 \%$ v/b). Hasil yang didapatkan, semakin banyak massa katalis yang digunakan, konversi yield yang diperoleh semakin tinggi yaitu mencapai $67 \%$. Viskositas dan densitas memenuhi standar biodiesel. Hasil uji surface area BET diperoleh surface area spesifik sebelum dan sesudah impregnasi berturut-turut adalah $89,937 \mathrm{~m}^{2} / \mathrm{g}$ dan $5,471 \mathrm{~m}^{2} / \mathrm{g}$. Analisa produk dengan menggunakan GC-MS dilakukan untuk mendapatkan jenis methyl ester sterarate, palmitat, dan Linoleat.
\end{abstract}

Kata kunci: abu sekam padi, biodiesel, kalsinasi, katalis heterogen, impregnasi

\section{PENDAHULUAN}

Sebagai Negara agraris, Indonesia merupakan penghasil padi. Menurut data Biro Pusat Statistik Kalimantan Timur pada tahun 2014 jumlah produksi padi mencapai 432.612 ton Gabah Kering Giling (GKG)(BPS, 2014).Menurut Folleto dalam Soeswanto (2011) sekam padi yang dihasilkan dari proses penggilingan sebesar $20 \%$ dari produksi padi. Dari produksi tersebut dihasilkan sekam sekitar 86.522 ton.

Menurut Ismunadji dalam Galang dkk (2013) Selama ini pemanfaatan sekam padi sangat terbatas, bahkan hanya menjadi limbah pertanian yang tidak diinginkan. Pemanfaatan sekam masih terbatas secara tradisional, yaitu digunakan untuk pembakaran batu bata dan selebihnya ditimbun lalu dibakar menjadi abu. Pada setiap penggilingan padi akan selalu kita lihat tumpukan bahkan gunungan sekam yang semakin lama semakin tinggi. Penanganan sekam padi yang kurang tepat akan menimbulkan pencemaran terhadap lingkungan.

Abu sekam padi hasil pembakaran yang terkontrol pada suhu tinggi $\left(500-600^{\circ} \mathrm{C}\right)$ 
akan menghasilkan abu silika yang dapat dimanfaatkan untuk berbagai proses kimia (Putro, 2007) diantaranya adalah sebagai support katalis. Berikut kandungan kimia dari abu sekam padi menurut Ismail dalam Prasad.R (2012) $\mathrm{SiO}_{2} 80 \%, \mathrm{Al}_{2} \mathrm{O}_{3} 3,59 \%$, $\mathrm{Fe}_{2} \mathrm{O}_{3}$ 0,41\%, $\mathrm{CaO} 3,84 \%, \mathrm{MgO} 0,25 \%$, $\mathrm{K}_{2} \mathrm{O} 1,26 \%, \mathrm{Na}_{2} \mathrm{O} 0,77 \%$. Pada penelitian sebelumnya $\mathrm{SiO}_{2}$ diekstraksi dari abu sekam padi dengan $\mathrm{KOH}$ dan digunakan sebagai katalis heterogen pada pembuatan biodiesel. Dengan melihat kandungan kimia pada abu sekam padi yang mempunyai kandungan $\mathrm{SiO}_{2}$ mencapai $80 \%$ dan kandungan kimia lainnya yang juga dapat di gunakan sebagai support katalis pada proses pembuatan biodiesel.

Pada penelitian sebelumnya telah dilakukan percobaan tentang manfaat sekam padi menjadi katalis pada proses pembuatan biodiesel seperti penelitian yang dilakukan oleh Santoso dkk pada tahun 2012 dimana bahan baku yang dipakai adalah zeolit dari sekam padi dan minyak biji kapuk yang dibuat menjadi biodiesel. Pada penelitian tersebut memvariasikan massa katalis zeolit sekam padi dan hasil terbaik yang didapatkan adalah pada saat massa katalis 2 gram dengan rendemen $21,94 \%$ biodiesel. Selain itu juga penelitian yang telah dilakukan Simanjuntak (2013) bahan baku yang dipakai sekam padi dan minyak sawit. Sekam padi di ekstraksi $\left(\mathrm{SiO}_{2}\right)$ dengan metode sol gel lalu dimodifikasi dengan $\mathrm{MgO}$ dan digunakan sebagai katalis heterogen pada pembuatan biodiesel. Pada penelitian tersebut memvariasikan komposisi katalis $\mathrm{MgO} / \mathrm{SiO}_{2}$ dan didapatkan hasil terbaik pada saat kondisi terbaik proses transesterifikasi minyak kelapa oleh katalis $\mathrm{MgO} / \mathrm{SiO}_{2}$ adalah menggunakan katalis dengan perbandingan $\mathrm{MgO} / \mathrm{SiO}_{2}$ 1:5, pada suhu $60^{\circ} \mathrm{C}$ selama 30 menit. Dengan capaian konversi minyak kelapa menjadi biodiesel sekitar $80 \%$
Penelitian ini bertujuan untuk mengetahui pengaruh penambahan abu sekam padi terkalsinasi dengan impregnasi $\mathrm{KOH}$ sebagai katalis pada proses pembuatan biodiesel dari minyak sawit. Dengan memvariasikan massa katalis abu sekam padi maka diharapkan dapat mendapatkan yield biodiesel yang terbaik.

Biodiesel merupakan senyawa metil ester dengan asam lemak rantai panjang seperti laurat, palmitat, stearat, oleat, dan lain-lain. Biodiesel merupakan bahan bakar alternatif dari sumber daya terbarukan (renewable resources ), dengan komposisi ester asam lemak dari minyak nabati antara lain: minyak kelapa sawit, minyak kelapa, minyak jarak pagar, minyak biji kapuk,dan masih ada lebih dari 30 macam tumbuhan Indonesia yang memiliki potensial untuk dijadikan bahan baku pembuatan biodiesel (Standar Nasional Indonesia, 2006). Biodiesel dapat dibuat dari minyak nabati maupun lemak hewan, namun yang paling umum digunakan sebagai bahan baku pembuatan biodiesel adalah minyak nabati. Minyak nabati dan biodiesel tergolong ke dalam kelas besar senyawa-senyawa organik yang sama, yaitu kelas ester asamasam lemak. Akan tetapi, minyak nabati adalah triester asam-asam lemak dengan gliserol, atau trigliserida, sedangkan biodiesel adalah monoester asam-asam lemak dengan methanol. Soerawidjaja (2006) dalam Sudrajat dkk (2003). Semua minyak nabati dapat digunakan sebagai pengganti bahan bakar namun dengan proses-proses pengolahan tertentu (Choo dalam Sudrajat dkk, 2003).

Minyak sawit adalah minyak nabati yang dapat dikonsumsi. Minyak inti kelapa sawit dihasilkan dari inti buah yang sama; perbedaan keduanya adalah warna (minyak inti kurang memiliki karotenoida dan tidak merah) dan mengandung lemak jenuh. Minyak ini memiliki banyak kegunaan, sebagai produk makanan, sumber bahan bakar nabati, dan beragam olahan kosmetik. 
Minyak sawit adalah produk minyak dasar yang dijual dalam pasar komoditi dunia meskipun banyak perusahaan yang memfraksinasikan minyak ini lebih lanjut menjadi minyak olein untuk minyak masak atau produk lain. Memisahkan minyak dan lemak dengan proses hidrolisis atau dengan pengkondisian alkalin (saponifikasi) akan menghasilkan asam lemak dengan gliserin (gliserol) sebagai produk sampingannya. Asam lemak yang terpisah adalah campuran dari rantai karbon panjang antara $\mathrm{C} 4$ hingga C18, tergantung tipe minyak atau lemaknya (Kemendag, 2015). Menurut Rohmadi (2010) asam lemak pada minyak sawit (Crude Palm Oil, CPO) berturut-turut adalah asam palmitat (C16:0), asam oleat (C18:0) dan asam linoleat (C18:2). Jumlah asam lemak jenuh dan tak jenuhnya seimbang.

Sekam padi merupakan produk samping dari industri penggilingan padi. Menurut Ismunadji dalam Galang dkk (2013) bahwa industri penggilingan dapat menghasilkan $65 \%$ beras, $20 \%$ sekam padi, dan sisanya hilang. Jika sejumlah sekam padi yang dihasilkan dari industri penggilingan padi tidak dikelola dan dimanfaatkan dengan baik maka akan menimbulkan pencemaran lingkungan. Sekam padi dianggap sebagai bahan yang kurang bermanfaat dan bernilai gizi rendah karena menurut Houston dalam Galang dkk (2013), sekam padi mengandung abu yang cukup tinggi.

Menurut Helmani dkk dalam Ricky dkk (2011) katalis heterogen merupakan pilihan baru untuk menggantikan katalis homogen berdasarkan korosivitasnya yang lebih rendah, kemudahannya untuk dipisahkan, dapat digunakan kembali, dan menghasilkan limbah beracun dalam jumlah yang lebih sedikit. Banyak dilakukan penelitian dalam mengembangkan katalis heterogen dalam bentuk padat. Katalis padat yang telah dikembangkan dan digunakan untuk proses transesterefikasi minyak nabati misalnya logam alkali atau logam alkali tanah yang diimpregnasi dalam $\mathrm{Al}_{2} \mathrm{O}_{3}$ (Noiroj et al, 2009), Alum (Aderemi et al, 2009) $\mathrm{K}_{2} \mathrm{CO}_{3}$ yang diimpregnasi dalam alumina/silika (Lukic et al, 2009). Katalis heterogen adalah katalis yang wujudnya berbeda dengan wujud reaktannya. Reaksi zat-zat yang melibatkan katalis jenis ini, berlangsung pada permukaan katalis tersebut. Reaksi fase gas dan fase cair dikatalisa oleh katalis heterogen biasanya lebih mungkin terjadi di permukaan katalis dari pada di fase gas atau fase cair. Untuk alasan ini, maka katalis heterogen disebut katalis kontak, selain itu katalis heterogen juga dapat digunakan kembali. Beberapa jenis katalis heterogen yang telah dilaporkan antara lain $\mathrm{CaO}, \mathrm{MgO}$.

Sebagai bahan bakar alternatif, biodiesel memiliki banyak keunggulan dibandingkan dengan bahan bakar minyak bumi diantaranya: ramah lingkungan, emisi pencemaran udara yang relative rendah, dapat terurai secara alami (biodegradable), dan bisa digunakan tanpa memerlukan proses modifikasi mesin. Biodiesel dihasilkan melalui reaksi transesterifikasi, yaitu reaksi antara minyak nabati atau lemak hewani dengan alkohol menghasilkan alkil ester (biodiesel) dan hasil samping gliserol dengan bantuan katalis (Noiroj et al, 2009). Katalis digunakan untuk meningkatkan kecepatan reaksi dan yield produk. Karena reaksi ini merupakan reaksi bolak-balik (reversible), dibutuhkan alkohol berlebih untuk menggeser kesetimbangan ke arah produk Helwani et al dalam Ricky dkk (2011). Konversi trigliserida menjadi metil ester atau etil ester melalui proses transesterifikasi dapat mengurangi berat molekul trigliserida hingga sepertiganya dan mengurangi viskositas hingga seperdelapannya, serta sedikit meningkatkan titik nyalanya (Lemigas, 2005).

Transesterifikasi (biasa disebut dengan alkoholisis) adalah tahap konversi 
trigliserida (minyak nabati) menjadi alkil ester, melalui reaksi dengan alkohol dan menghasilkan produk samping yaitu gliserol. Di antara alkohol-alkohol monohidrik yang menjadi kandidat sumber atau pemasok gugus alkil, adalah metanol yang paling umum digunakan, karena harganya murah dan reaktifitasnya paling tinggi (sehingga reaksi disebut metanolisis). Jadi, di sebagian besar dunia ini, biodiesel praktis identik dengan ester metil asam-asam lemak (Fatty Acids Metil Ester, FAME). Reaksi transesterifikasi trigliserida menjadi metil ester dapat dilihat sebagai berikut:

Transesterifikasi juga menggunakan katalis dalam reaksinya. Tanpa adanya katalis, konversi yang dihasilkan maksimum namun reaksi berjalan dengan lambat Satriyo dalam Maharani (2010). Katalis yang biasa digunakan pada reaksi transesterifikasi adalah katalis basa, karena katalis ini dapat mempercepat reaksi.

Produk yang diinginkan dari reaksi transesterifikasi adalah ester metil asamasam lemak. Terdapat beberapa cara agar kesetimbangan lebih ke arah produk, yaitu, menambahkan metanol berlebih ke dalam reaksi, memisahkan gliserol, menurunkan temperatur reaksi (transesterifikasi merupakan reaksi eksoterm).

\section{METODOLOGI}

Bahan: Sekam padi, minyak Sawit, methanol teknis, aquadest, $\mathrm{KOH} 1,9 \mathrm{~N}$, abu sekam padi yang dikalsinasi padea temperatur $500^{\circ} \mathrm{C}$ selama 3 jam dan abu sekam padi yang dikalsinasi padea temperatur $500^{\circ} \mathrm{C}$ selama 3 jam dengan impragnasi $\mathrm{KOH} 1,9 \mathrm{~N}$

Alat: furnace, Erlenmeyer vacuum ahsa,magnetic stirrer, oven, gegep, cawan, spatula, neraca digital, kondenser, gelas kimia, hot plate, lumpang alu, corong pisah $125 \mathrm{ml}$, kaca arloji.
Cara Kerja: Pada tahap pertama membersihkan sekam padi dengan air, mengeringkan sekam padi dengan oven pada suhu $110^{\circ} \mathrm{C}$ hingga beratnya konstan, lalu memasukkan sekam padi sebanyak 100 gram ke dalam cawan pengabuan kemudian memasukkan cawan pengabuan kedalam furnace pada suhu $500^{\circ} \mathrm{C}$ selama 3 jam kemudian mengeluarkan abu sekam padi dari dalam furnace lalu mendinginkan ke dalam desikator selama 15 menit. Prosedur impragnasi katalis abu sekam padi dengan menggunakan $\mathrm{KOH} 1,9 \mathrm{~N}$ yang pertama ialah melakukan perendaman katalis abu sekam padi dengan $\mathrm{KOH}$ 1,9 N selama 24 jam lalu memanaskan katalis yang telah direndam dengan $\mathrm{KOH}$ 1,9 $\mathrm{N}$ hingga semua $\mathrm{KOH}$ teruapkan. Menggunakan katalis hasil perendaman ke proses transesterifikasi minyak sawit lalu menyiapkan rangkaian alat labu leher tiga dengan kapasitas 1 liter. Menyiapkan condenser, mesin pengaduk, corong pisah, dan termokopel kemudian memasukkan methanol ke dalam gelas kimia beserta katalis dan diaduk selama 2 jam mengunakan magnetik stirrer kemudian memasukkan minyak sawit sebanyak 100 $\mathrm{ml}$ ke dalam labu leher tiga kemudian panaskan sampai suhu $60^{\circ} \mathrm{C}$ sambil diaduk dengan magnetic stirrer. Memasukkan metanol dan katalis ke dalam labu leher tiga waktu sampai 4 jam. Memasukkan hasil ke dalam corong pisah lalu mendiamkan selama 24 jam sehingga terbentuk 2 endapan biodiesel dengan gliserol lalu memisahkan endapan yang paling atas yang diduga biodiesel. Langkah selanjutnya melakukan pencucian dengan air hangat sampai bening lalu mengulangi langkah di atas dengan variasi massa katalis 10\%, 15\%, $20 \%$ untuk setiap proses pembuatan biodiesel kemudian memanaskan hasil pada suhu $100^{\circ} \mathrm{C}$ untuk menghilangkan methanol dan air serta menganalisa hasil produk pemisahan. 


\section{HASIL DAN PEMBAHASAN}

Penelitian ini bertujuan untuk mengetahui pengaruh katalis abu sekam padi dari hasil metode impregnasi $\mathrm{KOH}$ terhadap pembuatan biodiesel dari minyak sawit secara konvensional. Abu sekam padi terkalsinasi pada suhu $500^{\circ} \mathrm{C}$ selama 3 jam diimpregnasi dengan $\mathrm{KOH}$ 1,9 N. Penelitian menggunakan abu sekam padi dengan suhu kalsinasi $500^{\circ} \mathrm{C}$ selama 3 jam dan suhu kalsinasi $500^{\circ} \mathrm{C}$ selama 3 dengan impregnasi $\mathrm{KOH}$. Variabel yang digunakan sebagai indikator apabila minyak sawit telah menjadi biodiesel yang terbaik adalah dengan viscositas, densitas, asam lemak bebas, metil ester yang terbentuk dan yield. Pada penelitian ini hasil GC-MS yang ditampilkan adalah pada saat massa katalis $10 \%$ karena merupakan variasi massa terkecil dan sebagai perbandingan dengan hasil biodiesel yang lain. Berikut adalah data awal karakteristik minyak sawit sebelum transesterifikasi menggunakan katalis abu sekam padi. Berdasarkan Tabel 1 dapat dilihat bahwa nilai asam lemak bebas pada sampel awal adalah $<1 \%$ sehingga tidak perlu dilakukan metode esterifikasi.

Tabel 1. Hasil analisa bahan baku minyak sawit sebelum transesterifikasi

\begin{tabular}{llc}
\hline $\begin{array}{l}\text { Sifat fisika/kimiawi } \\
\text { biodiesel }\end{array}$ & Metode uji & Hasil \\
\hline $\begin{array}{l}\text { Densitas pada } 40^{\circ} \mathrm{C} \\
\left(\mathrm{g} / \mathrm{cm}^{3}\right)\end{array}$ & SNI-7182 & 0,9072 \\
$\begin{array}{l}\text { Viscositas } \mathrm{mm}^{2} / \mathrm{s} \\
(\mathrm{cSt})\end{array}$ & SNI-7182 & 40,9 \\
$\begin{array}{l}\text { Asam lemak bebas } \\
(\mathrm{mgKOH} / \mathrm{g}) \text { maks }\end{array}$ & SNI-7182 & 0,5 \\
\hline
\end{tabular}

Pada penelitian selanjutnya melakukan impregnasi dengan $\mathrm{KOH}$ 1,9 N. Menurut Prasad dkk (2012) impregnasi dilakukan untuk meningkatkan sisi aktif katalis.
Tabel 2. Surface area BET pada suhu $500^{\circ} \mathrm{C}$ selama 3 jam

\begin{tabular}{cc}
\hline Perlakuan Katalis & Hasil Analisa BET \\
\hline Tanpa Impregnasi & $89,937 \mathrm{~m}^{2} / \mathrm{g}$ \\
Impregnasi & $5,471 \mathrm{~m}^{2} / \mathrm{g}$ \\
\hline
\end{tabular}

Berdasarkan Tabel 2 diperoleh bahwa surface area pada katalis terimpregnasi $\mathrm{KOH}$ mengalami penurunan. Pada saat kalsinasi $500^{\circ} \mathrm{C}$ selama 3 jam surface area diperoleh $89,937 \mathrm{~m}^{2} / \mathrm{g}$ dan pada saat setelah impregnasi menjadi $5,471 \mathrm{~m}^{2} / \mathrm{g}$. Noiroj dkk (2009) menyebutkan bahwa $\mathrm{Al}_{2} \mathrm{O}_{3}$ dan $\mathrm{NaY}$ dapat dijadikan support katalis dengan cara impregnasi dengan $\mathrm{KOH}$ berbagai konsentrasi. Dari hasil surface area dari penelitian Noiroj dkk (2009) bahwa hasil yang didapat untuk surface area $\mathrm{KOH} / \mathrm{Al}_{2} \mathrm{O}_{3}$ dan $\mathrm{KOH} / \mathrm{NaY}$ diketahui bahwa semakin besar penambahan $\mathrm{KOH}$ maka surface area pada katalis juga akan menurun. Hal ini sesuai dengan katalis abu sekam padi yang telah diimpregnasi dengan $\mathrm{KOH}$, bahwa surface area setelah diimpregnasi $\mathrm{KOH}$ mengalami penurunan yang signifikan. Fungsi utama impregnasi dengan $\mathrm{KOH} \quad 1,9 \quad \mathrm{~N}$ adalah untuk meningkatkan sisi aktif katalis sehingga membuat abu sekam padi memiliki sisi aktif yang lebih tinggi dan dapat digunakan sebagai katalis heterogen pada pembuatan biodiesel. $\mathrm{KOH}$ digunakan sebagai sisi aktif katalis dan abu sekam adi sebagai support katalis. $\mathrm{KOH}$ mengisi pori-pori dari abu sekam padi sehingga membuat surface area menjadi menurun. $\mathrm{KOH}$ dengan $\mathrm{SiO}_{2}$ membentuk $\mathrm{KOH} / \mathrm{SiO}_{2}$ yang akan menjadi sisi aktif katalis. Setelah dilakukan impregnasi $\mathrm{KOH}$ kemudian di aplikasikan ke pembuatan biodiesel.

Berdasarkan Tabel 3 diperoleh hasil yang menunjukkan bahwa reaksi pembentukan biodiesel dapat berjalan. Pada pengabuan abu sekam padi pada suhu 
$500^{\circ} \mathrm{C}$ dan dilakukan impregnasi dengan $\mathrm{KOH}$ didapatkan viscositas dan densitas yang sesuai dengan standar SNI-7182:2012 sehingga membuat katalis abu sekam padi menjadi reaktif dan dapat merubah minyak sawit menjadi biodiesel. Hal ini diperkuat dengan beberapa parameter biodiesel yang diuji sesuai dengan standar baku biodiesel.

Tabel 3. Hasil analisa biodiesel dengan katalis abu sekam padi terkalsinansi $500^{\circ} \mathrm{C}$ selama 3 jam sebanyak $10 \% \mathrm{v} / \mathrm{b}$ dan impregnasi dengan $\mathrm{KOH}$

\begin{tabular}{lccc}
\hline \multicolumn{1}{c}{$\begin{array}{c}\text { Sifat } \\
\text { fisika/kimiawi } \\
\text { biodiesel }\end{array}$} & $\begin{array}{c}\text { Metode } \\
\text { uji }\end{array}$ & Standar & Hasil \\
\hline yield (\%) & & \multicolumn{2}{c}{60} \\
Densitas pada & SNI- & $0,850-$ & 0,8640 \\
$40^{\circ} \mathrm{C}(\mathrm{g} / \mathrm{cm} 3)$ & 7182 & 0,890 & \\
$\mathrm{Viscositas}^{2}$ & SNI- & $2,3-6,0$ & 5,56 \\
$\mathrm{~mm}^{2} / \mathrm{s}(\mathrm{cSt})$ & 7182 & & \\
\hline
\end{tabular}

\section{Pengaruh massa katalis terhadap yield biodiesel}

Berdasarkan Gambar 1 dapat dilihat bahwa yield biodiesel yang diperoleh mengalami peningkatan seiring dengan semakin banyak jumlah massa katalis yang dipakai. Seiring dengan semakin besarnya massa maka di dalam katalis semakin bertambah konsentrasi $\mathrm{KOH}$ sehingga meningkatkan sisi aktif katalis.

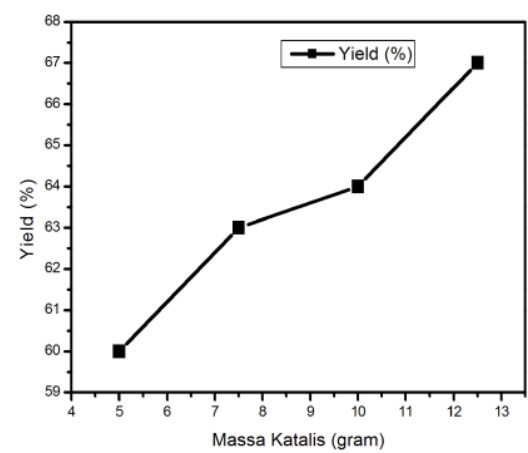

Gambar 1. Hubungan yield (\%) dengan massa katalis
Sisi aktif yang terbentuk adalah $\mathrm{KOH} / \mathrm{SiO}_{2}$ dan $\mathrm{KOH}$ yang masuk kedalam pori-pori katalis. Pada saat abu sekam padi dan $\mathrm{KOH} 1,9 \mathrm{~N}$ dipanasi dengan hot plate pada suhu $75^{\circ} \mathrm{C}$ selama 6 jam terjadi pemasukan gugus $\mathrm{KOH}$ ke dalam katalis yang terkalsinasi sehingga membuat katalis abu sekam padi menjadi reaktif.

Pengovenan pada suhu $110^{\circ} \mathrm{C}$ selama \pm 12 jam bertujuan untuk mengkonstankan berat katalis dan menghilangkan air sehingga katalis siap digunakan. Semakin banyak massa yang digunakan untuk reaksi transesterifikasi maka yield yang dihasilkan semakin tinggi. Yield tertinggi didapat pada massa katalis 12,5 gram dengan konversi sebanyak $67 \%$. Hal ini disebabkan karena katalis semakin banyak mempunyai sisi aktif sehingga membuat perolehan yield semakin meningkat.

\section{Analisis viscositas pada hasil biodiesel}

Viscositas merupakan faktor penting dalam biodiesel karena menurut Soetaredjo dkk (2010) viscositas bahan bakar memberi pengaruh besar pada injektor dan proses atomisasi bahan bakar. Jika viscositasnya terlalu kecil, bahan bakar tidak mampu menyediakan lubrikasi bagi pompa injeksi, namun jika viscositasnya terlalu timggi akan menghasilkan tetesan-tetesan yang lebih besar sehingga dapat menyebabkan pembakaran tidak sempurna. Menurut Standar Nasional Indonesia (SNI7182:2012) viscositas yang masih dapat digunakan untuk bahan bakar berbasis biodiesel adalah 2,6-6,0 cSt. Hasil dari viscositas pada penelitian ini dapat dilihat pada Tabel 4 dimana variasi massa yang yang digunakan pada penelitian ini masih masuk ke dalam standar biodiesel. Massa katalis tidak memberikan perubahan yang signifikan terhadap nilai viscositas. 
Tabel 4. Hasil analisis viscositas

\begin{tabular}{ccc}
\hline $\begin{array}{c}\text { Massa } \\
\text { Katalis }(\%)\end{array}$ & $\begin{array}{c}\text { Viscositas } \\
\text { Hasil Uji, cSt }\end{array}$ & $\begin{array}{c}\text { Vscositas } \\
\text { Standar SNI }\end{array}$ \\
\hline 10 & 3,8601 & $2,6-6,0$ \\
15 & 4,5082 & $2,6-6,0$ \\
20 & 4,7662 & $2,6-6,0$ \\
25 & 5,0813 & $2,6-6,0$ \\
\hline
\end{tabular}

\section{Analisis komposisi biodiesel dari minyak sawit}

Methyl ester hasil transesterifikasi minyak sawit menjadi biodiesel dianalisa menggunakan Gas Chromatography-Mass Spectroscopy (GC-MS). Analisis ini merupakan analisis kualitatif dan kuantitatif yang bisa digunakan untuk mengetahui jenis kandungan asam lemak dalam biodiesel beserta kuantitasnya. Methyl ester biodiesel yang telah dianalisis dengan GC-MS menunjukkan enam puncak dominan seperti disajikan pada Tabel 5.

Tabel 5. Hasil analisa GC-MS untuk hasil biodiesel yang diperoleh

\begin{tabular}{cc}
\hline Nama Senyawa & $\begin{array}{c}\text { Kuantitas } \\
(\% \text { area })\end{array}$ \\
\hline Methyl ester stearate & 47,45 \\
Methyl ester palmitate & 29,87 \\
Methyl ester linoleat & 16,92 \\
Arachidic acid methyl ester & 2,01 \\
Methyl ester myristate & 0,93 \\
Methyl ester oleate & 0,83 \\
\hline
\end{tabular}

Hasil analisa GC-MS terhadap kandungan methyl ester penyusun biodiesel yang diperoleh meliputi Methyl ester stearate, Methyl ester palmitate, Methyl ester linoleat, Arachidic acid methyl ester, Methyl ester myristate, dan Methyl ester oleate.

\section{KESIMPULAN}

Berdasarkan hasil penelitian abu sekam padi dapat digunakan sebagai katalis heterogen dalam pembuatan biodiesel dari minyak sawit dengan impregnasi $\mathrm{KOH} 1,9$ $\mathrm{N}$ dengan hasil yield tertinggi yaitu $67 \%$. Viscositas dan densitas pada hasil yang didapat memenuhi range biodiesel menurut SNI-7182:2012 Hasil GC-MS membuktikan bahwa hasil yang diperoleh adalah methyl ester. Yield biodisesel yang diperoleh sebesar $67 \%$ tentunya masih minimal, perlu dilakukan penelitian lebih lanjut untuk meningkatkan yield tersebut hingga mencapai $90 \%$.

\section{DAFTAR PUSTAKA}

1. Badan Pusat Statistik Kalimantan Timur. 2014. Produksi Padi Kalimantan Timur, http://www.bpskaltim.go.id/ 11 12 - 2014 10:40 WITA

2. Badan Standarisasi Nasional. 2014. Biodiesel SNI 04-7182-2006. http//www.bsn.go.id 11-12-2014 12.00 WITA

3. D. Mescha, 2007. Intensifikasi Proses Produksi Biodiesel. Institut Teknologi Bandung. Bandung

4. Fangrui, M., Milford, A.H., Biodiesel Production: a review. Biosource Tecnol 1999;70:1-15

5. Indra, K, R, Hardinoto, P, J, Ayucitra, A, Ismadji, S., 2011. Pemanfaatan Zeolit Alam sebagai Katalis Murah dalam Proses Pembuatan Biodiesel dari Minyak Kelapa Sawit. Prosiding Seminar Nasional Fundamental dan Aplikasi Teknik Kimia. Institut Teknologi Surabaya.

6. Lemigas. 2005. Naskah Akademik Rancangan Kebijakan Biodiesel. Jakarta: Pusat Penelitian dan Pengembangan Teknologi Minyak dan Gas Bumi

7. Galang F, A, M., Hanafi, M, R., Mardina, P. 2013, Ekstraksi Silika dari 
Abu Sekam Padi dengan Pelarut KOH. Universitas Lambung Mangkurat.

8. Noiroj, K., Intarapong, P., Luengnaruemitchai, A., Jai-In, S., 2009, A comparative study of $\mathrm{KOH} / \mathrm{Al} 2 \mathrm{O} 3$ and $\mathrm{KOH} / \mathrm{NaY}$ catalyst for biodiesel production via transesterification from palm oil. Renewable Energy. Bangkok. Thailand

9. Maharani, N,H. \& Zuliyana. 2010. Pembuatan Metil Ester (Biodiesel) Dari Minyak Dedak dan Methanol Dengan Proses Esterifikasi dan Transesterifikasi. Skripsi. Universitas Diponegoro. Semarang

10. Permatasari, A., Mayangsari, W dan Gunardi,I .,2013, Pembuatan Biodiesel dari Minyak Nyamplung (Calophyllum Inophyllum L) dengan Reaksi Transesterifikasi Menggunakan Katalis K2O/H-Za Berbasis Zeolit Alam

11. Eko Prasetya., 2012. Regenerasi Katalis Campuran $\mathrm{Al}_{2} \mathrm{O}_{3}$ dan hzsm -5 Melalui Reaksi oksidasi Berbasis Udara Bebas dari Reaksi Etanol Menjadi Hidrokarbon. Skripsi. Universitas Indonesia : Jakarta

12. Ram Prasad and Monika, P., 2012. Rice husk ash as a renewable source for the production of value added silica gel and its application: an overview. Bulletin of chemical engineering \& catalysis, Vol. 7(1) hal.1-25

13. Putro, A.L., dan Prasetyoko, D., 2007. Abu Sekam Padi Sebagai Sumber Silika
Pada Sintesis Zeolit ZSM-5 Tanpa Menggunakan Templat Organik. Akta Kimindo. Vol. 3(1), hal. 33-36.

14. Sudradjat, R. dan D. Setiawan. 2003. Teknologi pembuatan biodisel dari minyak biji jarak pagar. Laporan Hasil Penelitian. Pusat Litbang Teknologi Hasil Hutan. Bogor.

15. Soeswanto, B \& Lintang, N., 2011. Pemanfaatan Limbah Abu Sekam Padi Menjadi Natrim Silikat. Politeknik Negeri bandung.

16. S. Rahman, Supranto, P.K. Sri, 2012. Studi Proses Pembuatan Biodiesel dari Minyak Kelapa (Coconut Oil) dengan Bantuan Gelombang Ultrasonik. Universitas Gajah Mada

17. Soetaredjo, F. E., Ayucitra, A., Ismadji, S. \& Maukar, A.L. 2010. KOH/Bentonit cataliysts for tranesterification of palm oil to biodiesel. Applied Clay Science, In Press, Corrected Proof.

18. Sivasamy., Arumugam., Cheah, K,Y., Kemausuor, F., Sergeyzinoviev., Miertus, S., 2009. Catalytic Applications in the Production of Biodiesel from Vegetable Oils. ChemSusChe 2, 278-300

19. Widayat., Wicaksono, A,R., Firdaus, H,L., 2013. Pembuatan Katalis H-Zeolit dengan Impregnasi $\mathrm{KI} / \mathrm{KIO}_{3}$ dan $\mathrm{Uji}$ Kinerja Katalis Untuk Produksi Biodiesel. Jurnal teknologi Kimia dan Industri, Vol 2 (148-154). Universitas Diponegoro 